\title{
Materialism and indebtedness of low income consumers: Evidence from South Africa's largest credit granting catalogue retailer
}

\author{
G. Jacobs and E.v.d.M. Smit* \\ University of Stellenbosch Business School, \\ PO Box 610, Bellville 7535, Republic of South Africa \\ evdms@usb.ac.za
}

Received May 2010

\begin{abstract}
In South Africa, studies have found changes in consumption and credit usage over time to be significant amongst lowincome consumers. Yet, there has been limited empirical research on consumer behaviour in South Africa and even less on low-income consumerism. This study, which explores the relationship between materialism and indebtedness among a sample of low-income, instalment paying consumers of South Africa's largest catalogue retailer, aims to augment our understanding of these phenomena, whilst making some international comparisons.
\end{abstract}

The study assesses whether (i) consumers display strong characteristics of materialism and (ii) whether materialism is a significant variable in predicting the consumers' propensity for incurring debt. It is concluded that low-income consumers are indeed highly materialistic. The study further suggests the presence of statistically significant relationships between consumers' levels of indebtedness and the demographic variables age and gender. However, materialism and monthly income are not significant in determining a consumer's level of indebtedness.

While the decision to conduct the study on client data from one particular retailer, limits the extent to which the findings can be generalised to the larger South African population, the results do provide a number of important insights, which contribute to the scant body of literature on low-income consumer behaviour in the RSA.

*To whom all correspondence should be addressed.

\section{Introduction}

In recent years South Africans' spending patterns and levels of indebtedness have received significant media attention and hence regulators, monetary policy committees and businesses alike have been keeping a close watch on this country's evolving "culture of consumption" (Richins \& Dawson, 1990:169). A review of recent statistics provides a clear picture of the changing landscape of consumption and indebtedness in South Africa. The South African Reserve Bank (SARB, 2009), for example, reports that total household consumption expenditure, measured at current prices, increased by a staggering 375\% between 1994 and 2008. Even when measured at constant prices, household consumption expenditure has grown by as much as $78 \%$ between 1994 and 2008. Levels of indebtedness, measured by the SARB as the level of household debt relative to household disposable income, have shown similar trends. Using this measure, levels of indebtedness are shown to have increased by $44 \%$ between 1994 and 2008. Hurwitz and Luiz (2007: 108) also note a significant increase in levels of indebtedness between 1994 and 2002. They report that debt owed to retailers, on professional services and on cheque accounts and credit cards increased by $350 \%, 125 \%$ and $100 \%$ respectively during this period.

Prinsloo (2002:63) observes that increased levels of domestic spending can provide a very positive stimulus for economic growth, but not when it occurs at the cost of household savings, which is usually the case when there is a concurrent increase in both consumption and credit usage. In response, the South African government has promoted policies that aim to encourage domestic savings. Yet despite these actions Prinsloo (2000: 7) reports that gross saving rates for the household sector decreased from an average of $9 \%$ of gross domestic product (GDP) in the 1960s to just over $4 \%$ of GDP in the 1990s. At its lowest point, gross savings as a percentage of GDP reduced to only $2.9 \%$ in 1999. In more recent years this downward trend has continued, dipping below $2 \%$ of GDP from 2000 to 2005 and actually showing negative growth in 2006 to 2008 (SARB, 2009). Given the consistent growth in GDP and household disposable incomes in recent years, such a dramatic drop in savings during this period can only be explained by an increase in both consumption and indebtedness.

In understanding why consumption and credit usage might have increased, it is important to consider not only the sources of credit but also the users. A study by Schussler (2003) finds that debt was increasingly being incurred by lower-income earners. This finding was supported by studies performed by the Human Sciences Research Council (2003), which noted that debt levels were rising faster in the lower income categories than in the higher ones.

The current study seeks to provide insights into consumer behaviour in South Africa, specifically as to why levels of consumption and indebtedness have been steadily increasing by exploring three pertinent concepts in consumer behaviour research - materialism, indebtedness and low-income consumerism. 
Materialism is a universally recognised concept in consumer behaviour research, and is most commonly defined as "the importance a consumer attaches to worldly possessions" (Belk, 1984: 291). The concept is often described in relative terms i.e. an individual for whom material possessions are very important might be described as highly materialistic while an individual who attaches very little value to material possessions would be described as low in materialism. The reason why materialism is so relevant in consumer behaviour research is because the concept is so closely related to consumption. Previous research on materialism (Fitzmaurice \& Comegys, 2006; Watson, 1998), for example, clearly showed that individuals who are highly materialistic tend to spend more money, more time shopping and are more likely to incur debt. Ponchio and Aranha (2008:21) also found that materialism is an important variable in predicting a consumer's propensity for incurring debt. According to Watson (1998), the relationship between materialism and indebtedness should not be surprising. Watson (1998) concluded that individuals who score high on materialism also have more favourable attitudes towards debt. He (1998:203) noted that "with the availability of credit comes the ability to acquire things in the present and pay for them in the future". This ability is particularly appealing to the highly materialistic individual, for whom the immediate desire to consume can be overwhelming.

If we live in an increasingly materialistic society, which the rising consumption statistics seem to suggest, the regulators and monetary authorities are clearly justified in their concerns regarding consumption in this country; as an increased desire to consume can rapidly develop into an over-indebted society. South Africans' attitudes towards consumption and debt therefore form an important part of this study. However, not all parties share the same levels of concern regarding consumption and over-indebtedness. While the regulators and monetary authorities have largely been concerned with the welfare of society and consumer protection; businesses are looking for opportunities, particularly in low-income markets, where the desire to consume has shown rapid growth.

Under the apartheid regime, black low-income consumers would have been largely dismissed as a viable consumer market in South Africa. Today, however, many South African businesses accept that the buying power of lowincome consumers in this country has been grossly underestimated. In a recent report by the International Finance Corporation (IFC, 2007:19), it was estimated that low-income consumers accounted for as much as $75 \%$ of the (South African) population. What this means is that although the per capita income of these individuals is very low, the buying power of these consumers as a group, should not be ignored. It is the recognition of the significance of this group of consumers in South African society, which has prompted the need to earmark lowincome consumers as the focal point of this study.

The key objective of this study is to develop an understanding of the relationship between materialism and indebtedness within the South African low-income consumer population. To achieve this objective, we seek to understand whether recent patterns of increased consumption and indebtedness in South Africa, particular amongst low-income consumers, might be ascribed to higher levels of materialism.

As sample frame the data base of HomeChoice (Pty) Ltd ("HomeChoice"), which has been active in the low-income retail market for more than 20 years, was used. Prior to 1994 HomeChoice was one of only a few companies who sold goods actively and almost exclusively to black, low-income consumers. Also, unlike many other retailers who sell most of their goods for cash, HomeChoice offered goods on credit and accordingly retained far more information about their consumers than a typical retailer would. It has accumulated a wealth of data on low-income consumer behaviour and have access to a significant portion of the low-income consumer market, with whom they have fostered lasting relationships. The customer base of HomeChoice consisting of 160000 active consumers is unique, and well suited to this type of research, for the following reasons:

- HomeChoice's target market is consumers in LSM brackets 4-6, generally considered to be low-income consumers.

- The products sold by HomeChoice consists of home décor and furnishings, all non-essential household items for which the consumption decision is more likely to be based on materialistic desire than necessity.

- All HomeChoice customers enjoy access to credit, with products offered on terms of 6 or 16 months. A propensity to incur debt to consume is therefore an inherent attribute of a typical HomeChoice consumer.

Delineating the study in terms of the behaviour of consumers of one particular retailer, limits the extent to which the results can be generalised beyond the population of this particular retailer. National statistics serve largely only as a point of reference and no attempt has been made in this study to further generalise these findings to the greater South African population. However, despite the limitations in generalising the findings to the broader South African population, HomeChoice's dominance as a catalogue retailer suggests that the results are at a minimum representative of low-income catalogue retail customers in this country.

The choice of HomeChoice, also introduces other unique characteristics, which further influence the ability to generalise these findings. Two of the more significant characteristics are mentioned here for sake of completeness. First, as argued above, the nature of goods sold by HomeChoice i.e. durable, household goods might appeal more to individuals who are highly materialistic than to those that are low in materialism. One can therefore not assume that the consumers of a grocer who sells perishable goods, for example, would have the same levels of materialism as observed in this study, even if the consumers' levels of income are the same. Second, while not proven, the consumption behaviour of consumers of a catalogue retailer is generally assumed to be different from the behaviour of consumers who purchase goods in a store, where they have the opportunity to physically inspect the product prior to acquisition. Due to a dearth of research 
specific to catalogue retailers, this study does not explore how this distinction might influence levels of materialism or indebtedness.

The article proceeds as follows. Section 1 provides the introduction and relevant background information to the study. Section 2 provides an overview of the current literature regarding materialism, indebtedness and lowincome consumer behaviour. The next section gives an account of the methods used to achieve the research objectives. It motivates the use of a survey research design and further deals with the research instruments, data sources, sample sizes and data collection.

Section 4 presents the results of various data analysis techniques performed using the survey responses and Section 5 provides an interpretation of the results as well as a conclusion.

\section{Literature review}

\section{Materialism and its measurement}

In consumer related research, materialism and the desire to consume has been almost inextricably linked. Described by Richins and Dawson (1992) as the "centrality of possession and acquisition in consumers' lives" materialism speaks simply to the relationship individuals have with material possessions. Whether one enjoys buying them, owning them or showing them off to others - all of these ways in which we 'love' our possessions is merely an expression of our materialism.

Others have offered more formal definitions. Ward and Wackman (1971:422) describe materialism as "an orientation which views material goods and money as important for personal happiness and social progress". Their view alludes to a link between materialism and a capitalist society, where one's wealth is often measured by the material possessions one displays. Belk (1984:291) states that "materialism reflects the importance a consumer attaches to worldly possessions". Remarking that possessions are often regarded as influencing our sense of well-being, Belk (1984) sees a clear link between highly materialistic individuals and those individuals who 'enjoy living the good life'. Richins (1987: 352) also posits a positive link between materialism and "overall life satisfaction". She notes, however, that the pursuit of "material satisfaction" can be all consuming and likens materialistic possession to "an addictive drug of which consumers need larger and larger doses to maintain happiness" (Richins, 1987:353). Richins and Dawson (1992:304) believe that materialists use possessions as a benchmark for success. By definition therefore, a materialist believes that "the number and quality of possessions accumulated" would determine one's standing in society. This view is echoed by Fitzmaurice and Comegys (2006: 289) who state that "materialists are intent on acquiring goods in order to add further visible evidence that they are indeed successful or part of an elite rank in society."

These definitions emphasise the link between materialism and the desire to consume, but also highlight the fact that materialism is a very personal and relative term. Thus, while there are individuals who are highly materialistic - who in essence define who they are by what they possess - there are also individuals who are very low in materialism, who generally choose to lead a simple life, uncluttered by material possessions.

These definitions alone, however, do not allow one to measure which individuals are high in materialism or which are low in materialism. Fortunately there is sufficient consistency in the definitions to suggest that the concept can be broken down into a few descriptive variables or statements, which could ultimately be measured. In light of this suggestion and understanding the need to validate previous research in materialism, Belk (1984) and Richins and Dawson (1992) developed two independent scales through which materialism levels could be measured and compared. The Belk (1984) and Richins and Dawson (1992) materialism scales were not the first to be developed, but there were critical deficiencies in the earlier developed measures which prevented them from gaining widespread acceptance. Belk (1984:291) noted, for example, that previously developed materialism scales, like that of Campbell (1969), tended to measure "attitudes towards materialism" rather than materialism itself. Richins and Dawson (1992:307) also found that these earlier scales were often not psychometrically assessed or statistically validated.

The Belk (1984) materialism scale is based on three identifiable traits, which Belk believed to be closely related to materialism: possessiveness, non-generosity and envy. The traits were largely based on views prevalent in the materialism literature at the time. These views suggest that "at the highest level of materialism, possessions assume a central place in a person's life" (Belk, 1984: 291) and that these possessions were often used by materialists as a symbol of success.

In developing a measurable scale Belk identified 34 statements or items associated with materialism - 9 relating to possessiveness, 7 relating to non-generosity and 8 relating to envy. The items were combined into a questionnaire, using a 5-point Likert type scale. When subjected to the standard procedures recommended for scale development, the scale was found to have good validity and reliability. This led to the Belk (1984) scale being adopted as an accepted measure of materialism and being used in a number of later studies on materialism.

Despite the popularity of the Belk materialism scale, Richins and Dawson (1990) considered a scale based on personality traits to be an inappropriate measure of materialism. They noted that individual personality traits are generally developed in one's formative years and remain relatively unchanged over time, whereas materialistic tendencies are more situational and tend to evolve with time (Richins \& Dawson, 1990:170). The defining characteristics of traits therefore seemed inconsistent with the concept of materialism. Instead, they advocated that materialism should be viewed as a value, an attribute "which changes with social conditions and age" (Richins \& Dawson, 1990:170), and proposed a value-based materialism scale. Their 
material values scale (MVS) is based on three key themes: acquisition centrality, acquisition as the pursuit of happiness and possession-defined success.

Richins and Dawson's (1992) initial scale development attempts produced 120 statements related to materialism. Through refinement and testing, with adult consumer samples, the MVS was reduced to 18 items -7 related to centrality, 5 related to happiness and 6 related to success. This final scale was found to have even better validity and reliability than the Belk (1984) materialism scale.

The availability of not only one, but two dependable materialism scales resulted in a flurry of subsequent materialism related research. Richins (2004:209) found there to be more than 100 empirical studies on materialism since the MVS was published, but still believed that the MVS could be enhanced by developing a shortened version of the scale. One important reason cited by Richins (2004:209) for proposing a short form MVS was to reduce ambiguity. Richins (2004) noted that due to the similarity between some to the statements, it was sometimes difficult for respondents to distinguish between items. She therefore proposed four abridged versions of the MVS, a 15-item scale, a 9-item scale, a 6-item scale and a 3-item scale. Each scale was tested for reliability and validity using 15 data sets, taken from previous research in which the 18-item MVS had been used. The objective of the test was to identify a short form version of the MVS that was clearer and short enough to encourage more frequent use of the scale, without significantly reducing the reliability or validity of the scale. After extensive testing the short form that was found to best meet this objective was the 9-item MVS.

\section{Materialistic values in a developing economy}

One of the intriguing debates in materialism studies, and in consumer research in general, is the role that culture plays in influencing behaviour. In the late 1980's, for example, Belk was criticized by writers like Wallendorf and Arnould (1988) and Rudmin (1988), who suggested that the Belk materialism scale was "more appropriate to the United States than to other cultures, especially those of the Third World" (Ger \& Belk, 1990:186). Richins and Dawson (1990:170) also recognised that for any materialism scale to be dependable "it should strive to transcend cultures, subcultures and economic systems". In developing their material values scale therefore, they aimed to adopt themes that were universal and easily understood. There is now a growing body of research aimed at testing the materialism scale cross-culturally, with great emphasis often being placed on whether the materialism level of individuals in developed, more affluent economies differs from that of individuals in the less developed, low-income economies.

In response to early criticism Ger and Belk began work to enhance the Belk (1984) materialism scale, with the aim of achieving cross-cultural applicability. In modifying the scale, a number of new items, "developed for purposes of cross-cultural appropriateness" (Ger \& Belk, 1990:186), were added. Ger and Belk believed that, while their scale had not been extensively tested outside of the United States
(U.S.), materialism was no less applicable in a Third World country than in a First World country. They noted, for example, that "materialistic consumer culture arose in the developed world but is being emulated in the Third World at an increasing rate" (Ger \& Belk, 1990:188). They tested their modified scale amongst a cross-cultural group of students of American, British, French, German and Turkish descent. The most important finding of the study was that the Turkish, developing economy respondents, were the most materialistic of the group. This finding challenged the idea that materialism was only a developed world phenomenon. Later Ger and Belk (1996) expanded their cross-cultural research by extending their testing of the Belk materialism scale to twelve countries - six developed / affluent countries and six less developed / less affluent countries. Again a less developed country, this time Romania, was found to be the most materialistic. Based on the findings of this second study they were confident to dismiss the notion that materialism is a purely Western trait or that materialism is related to affluence. They also suggested that disparities in income might be a reasonable explanation why less affluent nations would be more materialistic. They stated that "the observation that materialism may be on the rise in less economically developed countries leads to the proposition that the havenots want more than the haves because they feel a keener sense of relative deprivation" (Ger \& Belk, 1996:58).

Webster and Beatty (1997) undertook a cross-cultural study between the U.S. and Thailand using the 18-item MVS. Previous cross-cultural research performed by Ger and Belk led the researchers to predict that Thai consumers would be more materialistic than US consumers (Webster \& Beatty, 1997:205). As further motivation to support this prediction, they also noted that "East Asian consumers ... seem to have an attraction for high image, high status products" (Webster $\&$ Beatty, 1997:205). The findings of the study validated their predictions - Thai consumers were indeed more materialistic than US consumers. Use of the MVS also allowed Webster and Beatty to conclude that Thai consumers attach more meaning to success than U.S. consumers, affirming the principle that culture influences consumer behaviour.

In the same year Eastman, Fredenberger, Campbell and Calvert (1997:52) undertook similar cross-cultural research to test "the relationship between status consumption and materialism", using the 18-item MVS. Student samples from China, Mexico and the U.S. were used in the study. Their research found Chinese students to be the most materialistic, followed by the US and then Mexico. Interestingly, as in the previous study, there were very high correlations between success and materialism across all countries. While the researchers ascribed the high levels of materialism in China to "status consciousness" and exposure to a "relatively Western lifestyle" (Eastman et al., 1997:55), they were unable to provide any plausible reason why the Mexican sample displayed significantly lower levels of materialism.

The 18-item MVS was also used by Griffin, Babin and Christensen (2004) in a European study on materialism. One of the main aims of their study was to determine whether there were cross-cultural differences in materialism between 
West and East European countries. The Russian sample was found to be the most materialistic. A more detailed review of results also revealed that the high materialism scores in the Russian sample were driven by a 'pursuit for happiness' rather than status. The majority of the Russian respondents believed, for example, that their "life would be better if (they) owned certain things (they) don't have" (Griffin et al., 2004:896), supporting Griffin et al.'s (2004:894) view that "difficulty in acquiring desired goods" can lead to heightened levels of materialism.

Ultimately, the consistent findings that developing / less affluent economies are often more materialistic than the developed economies, clearly suggests that materialistic values are pervasive in a developing economy environment.

\section{Age, gender, income and materialism}

The literature reports varying findings on the significance of age in relation to consumption and materialism. Sudbury and Simcock (2009:251), for example, found that in the UK, consumers over 50 spend more on luxury products like cars and travel. They also suggested that "as people age they become more dissimilar with respect to lifestyles, needs and consumption habits" (Sudbury \& Simcock, 2009: 251).

With regard to materialism, Belk (1984: 295) found that age was significantly related to two of his three identified materialism traits. More specifically age was found to be slightly negatively correlated with envy and slightly positively correlated with non-generosity. Micken (1995: 400) similarly found age to be related to envy, but also noted a statistically significant correlation between age and the overall Belk materialism scale. Finally Lerman and Maxwell (2006: 482) suggested that "materialistic traits are weakest among the oldest generation."

Gender also has an influence on consumption and materialism, with Belk (1984: 294) finding that "females were significantly less envious than males" and Fitzmaurice and Comegys (2006:296) recording that gender was an important variable in "predicting both time shopping and spending." Consistent with views expressed by Bryce and Olney (1991:241), the nurturing nature of females make them more likely to "desire objects" that would create a more inviting home. This explains why an overwhelming majority of HomeChoice customers, and consequently the majority of respondents to this survey, are female.

Previous research on income and materialism also provided some conflicting results. Ger and Belk (1990:191) for example believed that "some bare minimum of economic means" was sufficient to influence materialism, particularly in environments where significant inequalities in income created a sense of "relative deprivation" which served to fuel rather than discourage materialism. Ponchio and Aranha (2008), however, found that at low-income levels there was no association between materialism and income.

\section{Low-income consumer behaviour in South Africa}

Of particular interest is whether the current attributes and behaviour of South Africa's low-income consumers might predispose them to be more materialistic, as was the case for other developing economies. We depart from an exploration of the demographics of the South African low-income consumer. The information provided is based on demographic surveys performed or reported on by the Bureau of Market Research (BMR).

Six key demographic characteristics are presented namely Income, Gender, Employment, Education, Community and Age:

Table 1: Personal income by population group INCOME DISTRIBUTION (\%)

\begin{tabular}{l|c|c|c|c}
\hline $\begin{array}{c}\text { Monthly income } \\
\text { category }\end{array}$ & African & Coloured & Asian & White \\
\hline No income & 26 & 28 & 33 & 17 \\
\hline R0-R1 999 & 48 & 40 & 19 & 14 \\
\hline R2 000-R3 999 & 13 & 13 & 13 & 12 \\
\hline R4 000-R7 999 & 8 & 12 & 18 & 23 \\
\hline R8 000 + & 4 & 7 & 16 & 34 \\
\hline Total & $\mathbf{1 0 0}$ & $\mathbf{1 0 0}$ & $\mathbf{1 0 0}$ & $\mathbf{1 0 0}$ \\
\hline
\end{tabular}

Source: BMR (2008: 16)

- Of the total population within each population group $87 \%$ of Africans, $81 \%$ of coloureds and $65 \%$ of Asians earn less than R 4000 per month;

- One third of the Asian population reported earning no income at all i.e. are formally unemployed;

- $\quad 34 \%$ of white respondents earned salaries greater than R 8000 per month, compared to only $4 \%$ of Africans. Hurwitz and Luiz (2007:107) believe that statistics like these are exacerbated by the "government's policy on black economic empowerment", which has inadvertently lead to a small number of blacks reaping most of the benefits, with little "trickl(ing) down to the African masses".

Table 2: Gender and employment profile of the lowincome consumer

\begin{tabular}{l|c|c|c|c}
\hline \multicolumn{5}{c}{ GENDER AND EMPLOYMNT (\%) } \\
\hline $\begin{array}{c}\text { Monthly income } \\
\text { category }\end{array}$ & Male & Female & Employed & Unemployed \\
\hline R0-R2 999 & 49 & 51 & 30 & 70 \\
\hline R3 000-R6 999 & 49 & 51 & 48 & 52 \\
\hline
\end{tabular}

Source: BMR (2007: 27, 31)

- $\quad$ Females are only marginally worse off than males in the low-income consumer categories.

- $\quad$ Approximately $70 \%$ of respondents earning less than R 3000 per month are unemployed, while just over half of respondents earning between R 3000 and R 6 999 per month stated that they were unemployed. The statistic is understandable for individuals in the lowest income bracket, but in the higher income bracket it is indicative of income being earned through government support systems such as social grants or pensions, remittances or through the informal sector. 
Table 3: Level of education of low-income consumers

\begin{tabular}{l|c|c|c|c}
\hline \multicolumn{5}{c}{ EDUCATION (\%) } \\
\hline $\begin{array}{c}\text { Monthly income } \\
\text { category }\end{array}$ & $\begin{array}{c}\text { No } \\
\text { education }\end{array}$ & $\begin{array}{c}\text { Some } \\
\text { education }\end{array}$ & $\begin{array}{c}\text { Completed } \\
\text { secondary } \\
\text { education }\end{array}$ & $\begin{array}{c}\text { Tertiary } \\
\text { education }\end{array}$ \\
\hline R0-R2 999 & 10 & 76 & 13 & 1 \\
\hline R3 000-R6 999 & 2 & 55 & 34 & 9 \\
\hline
\end{tabular}

Source: BMR (2007: 33)

- $\quad$ On average only $5 \%$ of all respondents earning less than R 7000 have education at the tertiary level.

- The vast majority of respondents in this group, around $89 \%$, have had some form of education, although for many this would probably only refer to some primary level of education.

Table 4: Community profile of low-income consumers

\begin{tabular}{l|c|c|c|c}
\hline \multicolumn{5}{c}{ COMMUNITY (\%) } \\
\hline $\begin{array}{c}\text { Monthly income } \\
\text { category }\end{array}$ & Metro & $\begin{array}{c}\text { City / } \\
\text { Large } \\
\text { Town }\end{array}$ & $\begin{array}{c}\text { Small } \\
\text { Town / } \\
\text { Village }\end{array}$ & Rural \\
\hline R0-R2 999 & 17 & 9 & 61 & 13 \\
\hline R3 000-R6 999 & 60 & 14 & 24 & 2 \\
\hline S0ur
\end{tabular}

Source: BMR (2007: 46)

- $\quad$ About $74 \%$ of respondents earning less than R 3000 per month live in rural areas or in small towns or villages.

- $\quad$ The same proportion of respondents earning between $\mathrm{R}$ 3000 and R 6999 live in urban areas.

It should be noted that the distinction between urban and rural consumers in this country is important for a number of reasons. For one, the community in which an individual stays, affects that individual's access to markets and therefore their ability to earn income and to meet their consumption needs. Prahalad (2006) considers a lack of market access to be one of the key challenges facing lowincome consumers and advises businesses that wish to market to these consumers to develop distribution channels that "take into account where the poor live, as well as their work patterns" (Prahalad, 2006: 18). Secondly, the community in which an individual stays affects that individual's access to employment. This is affirmed by the statistics above, which clearly suggests that in order to gain access to a decent income, people have had to move out of the rural areas and into the cities. Finally, consumer research in South Africa consistently depicts an image of rural poverty vs urban wealth. It is this very image which forms the basis of Burgess's (2002) seminal research on South African consumer behaviour. In his study, which seeks to understand the changing identity of consumers in postapartheid SA, he categorises consumers into four primary groups ranging from 'Rural Survivalist' to 'Urban Elite'.
Table 5: Age profile of low-income consumers

\begin{tabular}{l|c|c|c|c}
\hline \multicolumn{5}{c}{ AGE (\%) } \\
\hline $\begin{array}{c}\text { Monthly income } \\
\text { category }\end{array}$ & $\begin{array}{c}\mathbf{1 6 - 2 4} \\
\text { years }\end{array}$ & $\begin{array}{c}\mathbf{2 5 - 3 4} \\
\text { years }\end{array}$ & $\begin{array}{c}\mathbf{3 5 - 4 9} \\
\text { years }\end{array}$ & $\mathbf{5 0}+$ years \\
\hline R0-R2 999 & 22 & 25 & 27 & 26 \\
\hline R3 000-R6 999 & 18 & 28 & 34 & 20 \\
\hline
\end{tabular}

Source: BMR (2007: 29)

- At very low income levels age is not a distinguishing factor. There is a roughly equal distribution of individuals across the age groups;

- In the R 3000 to R 6999 per month income bracket however, the majority of respondents, just over one third, are between 35 and 49 years of age;

- The trend in age distributions in this higher income bracket suggests a link between the level of income earned and years of experience.

In addition to demographic profile, two telling aspects of low-income consumerism that should be explored are: one, what influences of low-income consumer's buying behaviour and two, what low-income consumers buy.

Sawady and Teschner (2008) offer some interesting insights into the mind of the low-income consumer. They suggest, for example, that low-income consumers have a "collective mindset" in which they view themselves in the context of others and often make acquisitions based on whether that acquisition will appease their sense of belonging (Sawady \& Teschner, 2008: 98). They also propose that the "reasoning system of low-income consumers" is shaped by shared experiences (Sawady \& Teschner, 2008:96). This finding highlights the potential power of word-of-mouth marketing strategies amongst low-income consumers. Their findings depict a certain 'culture' amongst low-income consumers that is very much in keeping with the cultural norms of the South African mass market consumer. Cant, Brink and Brinjball (2006: 65), for example, states that "peoples of African descent are linked by shared values ... [that include] an emphasis on community rather than on the individual". Cant et al. (2006: 74) also refer to the influence of reference groups on consumer behaviour. They define a reference group as "any person or group that serves as a point of comparison or reference for an individual consumer." They found that for the black consumer in South Africa, the main reference groups are "family members, peer pressure groups and, in particular, role models".

While 20 years ago Vleggaar (1978:8) considered these 'role models' as being the "White" or "Western" man, today there are a select group of 'black elite' - generally those who have gained higher income and status as a consequence of black economic empowerment - who now fulfil this role. This group of black elite includes politicians, entrepreneurs, young black professionals (affectionately referred to as 'buppies'), musicians and academics. 
In emulating these role models low-income consumers not only aspire to reach the same social status but also to acquire the possessions they own. Information from four emerging market countries, as provided by the IFC (2007), has been used to analyse and compare household expenditure by sector.

Table 6: Household expenditure by sector - a four country comparison

\begin{tabular}{|c|c|c|c|c|}
\hline \multicolumn{5}{|c|}{ HOUSEHOLD EXPENDITURE BY SECTOR } \\
\hline Sector & $\begin{array}{l}\text { South } \\
\text { Africa }\end{array}$ & Brazil & Russia & India \\
\hline Food & 43,0 & 30,4 & 41,7 & 70,5 \\
\hline Housing & 11,0 & 5,2 & 24,0 & 2,4 \\
\hline Water & 1,3 & 0,9 & 0,7 & 0,1 \\
\hline Energy & 6,4 & 6,7 & 4,8 & 11,8 \\
\hline Household goods & 11,2 & 14,3 & 9,7 & 1,7 \\
\hline Health & 1,4 & 6,6 & 6,8 & 2,9 \\
\hline Transportation & 5,6 & 10,7 & 2,7 & 2,1 \\
\hline ICT & 1,8 & 3,0 & 1,0 & 0,6 \\
\hline Education & 2,2 & 1,3 & 0,9 & 1,2 \\
\hline \multirow[t]{2}{*}{ Other } & 16,1 & 20,9 & 7,7 & 6,7 \\
\hline & 100,0 & 100,0 & 100,0 & 100,0 \\
\hline
\end{tabular}

Source: IFC (2007: 117, 128, 140, 143)

Low-income consumer behaviour is not universally consistent. Where South Africans, for example, spend $43 \%$ of their budget on food, the comparable percentage for India is a massive $70.5 \%$.

Another category in which there are significant crosscultural differences is in housing. Of the four nationalities, Russians spend the highest relative proportion of their budgets on housing at $24 \%$. South Africans spend less than half that amount and Indians only one-tenth of this budget. It should be noted that India's low spend is probably influenced by the high proportion of rural consumers (roughly $71 \%$ of India's low-income consumer population).

The item of greatest interest for this study is expenditure on household goods as this is the sector in which HomeChoice is a player. According to the IFC, South African low-income consumers spend roughly $11,2 \%$ of their total expenditure budgets on household goods. The only selected country which spends a greater proportion is Brazil. A possible reason for Brazil's relatively high expenditure on household goods could be linked to the success of companies like Casas Bahia, a mass market retailer that focuses on selling household goods at low prices to low-income consumers, predominantly on credit (Halasz: 2004). The company is regarded as one of the greatest success stories in "retail for the poor" (Prahalad: 2006:159).

After food, South African's biggest expenditure sector is "Other". This category undoubtedly includes a number of luxury items like cellphones and branded clothing, all aspirational purchase items i.e. items that reflect a desire to "keep up with the Jones's".
The final significant variable in assessing South Africa's low-income consumer is buying power. The IFC (2007) estimates that there are roughly 4 billion low-income consumers worldwide, representing a global market share of roughly $\$ 5$ trillion. For South Africa alone this buying power is estimated to be roughly $\$ 40.3$ billion, which represents a $30 \%$ share of total consumption expenditure in this country (IFC, 2007:143). Prior to 1994, despite this consumer groups' clear majority in population terms, their inferior position in South African society during the apartheid years would have made them an undesirable target population for many businesses. Today, however, Hurwitz and Luiz (2007:111) reports that "established businesses" are recognising South Africa's low-income consumer population as a "viable and (largely) untapped market." This increased focus on the low-income market has been met with mixed reactions. Those in favour argue that many South Africans now enjoy access to goods and services, which during apartheid years they were largely denied. Prahalad (2006) contends that the "greatest harm large firms can do to lower income households is to ignore them altogether" (Hurwitz \& Luiz: 2007:112). Critics, however, believe that low-income consumers are being exploited, accusing businesses of excessive costs and the irresponsible granting of credit, which have led to many low-income consumers becoming over-indebted. Hurwitz and Luiz (2007:114) confirm that "in order to price higher risk" in low-income markets, businesses "charge exceptionally high interest rates".

\section{South African attitudes towards debt}

Early in 2009 the South African National Credit Regulator (NCR) reported that as many as 17 million people, nearly $40 \%$ of the total population, were deeply indebted. The country's ratio of household debt to disposable income - a widely accepted measure for consumer indebtedness in SA (Mafu, 2007: 4; Futuse, 2006:5) - has increased from 53,2\% in 1994 to 76,9\% in 2007. This growth in indebtedness has not been consistent, and has been influenced by factors such as:

- The introduction of store cards by retail outlets during the mid 1990's, which led to a slow and steady increase in indebtedness between 1994 and 1996, reaching a then all time high of $61 \%$ (Prinsloo, 2002:70-71).

- $\quad$ More stringent monetary policies, which resulted in prime lending rates rising from $19,5 \%$ in 1996 to a high of $25,5 \%$ in 1998 , kept indebtedness levels in check during this period.

- $\quad$ Rapid growth in levels of disposable income during 1999 to 2002 tempered demand for credit during these years (Prinsloo, 2002:71).

- $\quad$ Escalating house prices, which grew at around $20 \%$ to $30 \%$ per annum between 2004 and 2005 led to significant increases in mortgage credit. 
After June 2005, in the wake of tabling the National Credit Act (NCA) before parliament, banks and other credit providers flooded the market with credit. As a result, levels of indebtedness rapidly increased between June 2005 and June 2007, the month in which the NCA became effective.

While national data provides a clear picture of rising levels of indebtedness, it still masks the real depth of individual indebtedness. Hurwitz and Luiz (2007:47) reveal that $60 \%$ of urban working class South Africans are committed to paying debt instalments of more than $30 \%$ of their gross monthly income, $28 \%$ are committed to paying more than $100 \%$ of their gross monthly income and $10 \%$ are committed to paying more than 200\%. Collins (2008:470) argues that the indebtedness of low-income consumers in particular have risen more rapidly relative to other income groups, largely due to better access to credit. Prinsloo (2002: 71) notes, for example, that "the growth in the microlending industry" has been instrumental to increasing access to credit in the low-income markets. Hurwitz and Luiz (2007:108) also found evidence of credit providers "increasing market penetration into previously 'underserved' markets at the lower end of the income spectrum."

Another reason offered for the rising indebtedness levels of low-income consumers is the growing levels of income disparity. Boushey and Weller (2008:6) believes that "growing income dispersion gave rise to increased demand for credit, particularly among low-income and middleincome families", an assertion not unlike that of Ger and Belk (1996) who stated that income inequality creates a repressed desire to consume - a desire which can be realised through credit access.

In today's consumer driven society, where credit is so easily and widely available, acquiring goods on credit has become more socially acceptable than ever before. This is particularly true for the highly materialistic individual, for whom debt is a welcome instrument "to satisfy their strong acquisitive desires" (Watson, 1998:203).

Understanding the role of materialism and indebtedness is one of the key objectives of this study. There is, seemingly, a natural link between materialism and indebtedness. Intuitively it stands to reason that the materialist - defined by Belk (1984:291) as one who attaches great importance to the possession of material things - would be more willing to incur debt to acquire such things.

One researcher who has sought to understand this relationship is Watson. In a first study Watson (1998) studied not only these two variables, but also considered the impact of materialism on attitudes towards spending and levels of debt. Given the acquisitive nature of materialism, Watson (1998: 203) assumed that materialists would (i) spend more (ii) have a more favourable attitude towards debt, and (iii) be more highly indebted. He also assumed that materialism would be an important variable for predicting levels of debt. To test these assumptions Watson conducted a survey on a university campus in New Zealand. The results of the survey supported assumptions (i) and (ii).
In particular, respondents with high levels of materialism scored roughly $8 \%$ higher on a "spending tendency" scorecard, and about $4 \%$ higher on an "attitudes towards debt" scale. The responses did not, however, suggest that the level of indebtedness of highly materialist individuals were significantly different from those with low levels of materialism. Finally, in developing a regression model for debt, the three significant variables for predicting debt were found to be age, attitude towards debt and entertainment. Interestingly, in the final equation, materialism was not found to be a statistically significant predictor of debt (Watson, 1998:205).

The objectives of Watson's (2003) second study were largely the same as the first. The only material change was to include an examination of levels of materialism in relation to individuals" "propensity to save" (Watson, 2003:723). A number of changes in the method in which the study was conducted were introduced however. First, the sample selected was an adult sample; second, the study was conducted in the U.S.; third, the scales used for measuring levels of debt and attitudes differed and finally, the questionnaires were delivered by mail. Despite changes to the method of the study, the outcomes remained largely unchanged. Materialists were still found to have higher spending tendencies and more favourable attitudes to debt. They were also found to be more likely to take on debt, although differences in the total amount of outstanding debt at the time of the study were not found to be statistically significant. A new finding was that individuals with low levels of materialism have more positive attitudes towards savings (Watson, 2003:731-735).

Ponchio and Aranha designed a study which aimed to explore "the influence of materialism on consumer indebtedness among low income individuals" (Ponchio \& Aranha, 2008:21) utilising poor households in Sao Paolo, Brazil using the adapted 9-item MVS. The most important finding of the study was that, unlike in the study performed by Watson (1998), for the low-income population observed in this study, materialism was a significant variable in predicting indebtedness (Ponchio \& Aranha 2008:31). In the final regression equation materialism, age, gender and income were all found to be significant variables.

\section{Research design and methodology}

Following the example of researchers who had previously studied materialism and indebtedness, the most appropriate research design for this study was deemed to be one which allowed for empirical testing; for which quantitative, primary data could be obtained and where a moderate degree of control or structure could be enforced. Accordingly, a survey research design was selected.

Understanding the target audience is valuable in determining the level of complexity of questions which should be included in the survey. For this study the target audience was clearly defined as the HomeChoice customer, but given that the typical HomeChoice consumer is a low-income earning African woman, factors such as the language and level of education of the target audience were carefully considered when designing the survey questionnaire. 
Although for many of the HomeChoice customers, English was not expected to be their first language and education levels were expected to be generally low, there were two important advantages for the target population in this survey as compared to that of the Ponchio and Aranha (2008) survey. Firstly, the language in which the company communicates with its customers has always been in English. A survey presented to the HomeChoice customer in English was therefore expected to be easily understood and therefore no attempt was made to translate the questionnaire into any language other than English. Second, HomeChoice regularly performs market surveys under its customers, so that the audience receiving the questionnaire would most likely have had experience completing similar questionnaires and therefore would be comfortable receiving and responding through this medium.

The second important consideration, which affected both the length and the structure of the questionnaire, was how the survey would be delivered to the customer. Due to the broad geographical distribution of the HomeChoice customer base, mailed self-completion surveys were regarded as being the most effective means of delivery. More importantly, it was the medium in which previous HomeChoice market surveys had most commonly been delivered and therefore the medium with which HomeChoice customers would be most familiar.

For convenience, and in keeping with previous HomeChoice market surveys, the questionnaire was printed in the HomeChoice Club magazine, which is mailed to HomeChoice customers on a bi-monthly basis. The questionnaire, however, had to be restricted to one page, therefore careful consideration was given to both the survey questions and the survey instructions to ensure that they were clear and concise. Attention was also given to the structure and presentation of the survey, to ensure that it was aesthetically appealing. As a further inducement customers were given the chance to win a R3 000 shopping voucher at a popular retail store. This added incentive largely sought to address the concern raised by Hair et al. (2007: 210) that response rates for mailed surveys tend to be very low.

The third consideration was whether respondents should be allowed to maintain their anonymity. Allowing a respondent to maintain anonymity often increases response rates, particularly if the questionnaire deals with a subject matter considered as personal or sensitive. Unfortunately the nature of this study required the researcher to make inferences based on key demographic information about the respondent, which was best acquired by having the customer identify themselves. Respondents were therefore asked to include their name and HomeChoice customer number on the survey form. This information was then used to obtain certain demographic information about the respondent directly from the HomeChoice customer database.

The final consideration was determining which questions would have to be asked, or what scales would need to be used. The information regarded as most pertinent in this regard was determining the respondents' levels of materialism and levels of indebtedness. It was deemed appropriate that any questions or scales used should be succinct, plainly-worded and unambiguous. To measure materialism therefore, the Richins (2004) 9-item shortened MVS, as adapted by Ponchio and Aranha (2008) was used. The nine statements, corresponding to the 9-item MVS, were listed in the questionnaire, with each statement needing to be ranked by the respondent based on a five point scale ranging from 1 = "I strongly disagree" to 5 = "I strongly agree". The benefit of using the same survey statements as was used by Ponchio and Aranha (2008) was that the results of this study could be compared to results obtained by these researchers in Sao Paolo. To measure indebtedness respondents were asked to indicate the number of retail store accounts they held. To assist the respondent in providing this measure, they were supplied with a list of stores which offer store accounts from which they could make a selection. A blank line was also provided on which they could fill in the names of any other accounts held, which were not on the list provided.

Once the questionnaire was finalised, the survey was pretested with a group of typical HomeChoice customers. The purpose of the pre-testing was to test users' understanding of the survey scale and instructions and the clarity of the statements. The test group reported that the scale used and the instructions were easily understood and the statements were clear and unambiguous.

A sample size of 120 was calculated to provide estimates of materialism at a precision of 0,25 and at a $95 \%$ confidence level.

The survey produced an initial list of 290 respondents. This initial list, however, included a number of individuals who earned an income greater than the low-income threshold defined for purposes of this study, of R 7000 per month. Therefore, once all completed surveys were recorded, a secondary list, including only those respondents earning $\mathrm{R}$ 7000 or less per month, was compiled. This secondary list included 217 respondents, well above the suitable sample size of 120 respondents required for this study. It was this sample that formed the basis for all later analysis performed in the study.

Based on the findings of previous studies, age, gender and income have been identified as the three most important demographic variables for a study of this nature. Table 7 depicts the age, gender and income levels of respondents for this study.

In the sample of consumers who responded to this survey, the ages ranged from 22 years old to 84 years old. The most common age group was between 35 and 49 years old, with respondents in this age group accounting for $41,94 \%$ of the total sample. The youngest age group, including individuals aged from 22 years old to 24 years old, accounted for only $4,61 \%$ of the total sample. The low percentage is partially explained by the small age bracket, but also by the nature of the product sold by HomeChoice, which is targeted at a slightly older market. 
Table 7: Demographic composition of respondents

\begin{tabular}{l|c|c}
\hline \multicolumn{1}{l|}{ Age: } & & \\
\hline Between 22 and 24 & 10 & $4,61 \%$ \\
\hline Between 25 and 34 & 69 & $31,80 \%$ \\
\hline Between 35 and 49 & 91 & $41,94 \%$ \\
\hline Over 50 & 47 & $21,66 \%$ \\
\hline Gender & $\mathbf{2 1 7}$ & \\
\hline Male & & \\
\hline Female & 44 & $20,28 \%$ \\
\hline & 173 & $79,72 \%$ \\
\hline Monthly income & $\mathbf{2 1 7}$ & \\
\hline From R 500 to R 2000 & & \\
\hline From R 2001 to R 3000 & 86 & $39,63 \%$ \\
\hline From R 3001 to R 4000 & 39 & $17,97 \%$ \\
\hline From R 4001 to R 7000 & 52 & $18,43 \%$ \\
\hline Over R 7000 & 0 & $23,96 \%$ \\
\hline & $\mathbf{2 1 7}$ & \\
\hline
\end{tabular}

An overwhelming majority of the respondents to this study, just less than $80 \%$, were female. This ratio is consistent with the gender profile of the HomeChoice customer base, but not at all in line with national statistics, which suggests that the gender split of low-income consumers in this country is roughly $51 \%$ female and $49 \%$ male. Again these statistics would be influenced by the nature of the product sold by HomeChoice.

The average level of monthly income of the respondents was roughly $\mathrm{R} 2,900$. The majority of the respondents, roughly
$58 \%$, earned less than R 3,000 per month. Due to the lowincome threshold used for this study, none of the respondents earned more than $\mathrm{R}$ 7,000 per month.

By stratifying customers by age, gender and income, it was possible to use Chi-squared testing to assess whether the demographic profile of customers who responded to this study differed from the distribution of customers based on the national profile of low-income consumers. The results show that the characteristics of sampled respondents are statistically significantly different for age, gender and income. More specifically, the sample contains less of the very young, the very poor and males relative to the population. For this reason conclusions in this study will only be made with respect to the HomeChoice customer base.

As previously stated, the materialism scale selected for this study was based on the Richins (2004) 9-item shortened MVS, as adapted by Ponchio and Aranha (2008). One of the modifications made by Ponchio and Aranha (2008) was to reword any negatively worded statements found in the original Richins (2004) scale into positively worded statements. This adaption served two important purposes. Firstly, statements that are positively worded tend to be more positively received by respondents, increasing the possibility of a response. Secondly, all responses could be scaled and measured in the same way and there was no need to reverse the code of any of the responses.

As an initial analysis of the materialism scale responses, each of the nine materialism statements were described through use of the basic descriptive statistics of range, median, mean and standard deviation (see Table 8).

Table 8: Summary of materialism scores and reliability

\begin{tabular}{|c|c|c|c|c|c|c|c|c|c|c|}
\hline Item & \begin{tabular}{|c|} 
Description \\
\end{tabular} & Count & Min & Max & Median & Mean & Std Dev & Variance & $\begin{array}{c}\text { Sum of } \\
\text { Variances }\end{array}$ & $\begin{array}{c}\text { Alpha if item } \\
\text { deleted }\end{array}$ \\
\hline 1 & $\begin{array}{l}\text { I admire people who own expensive homes, } \\
\text { cars and clothes (S) }\end{array}$ & 217 & 1 & 5 & 3,00 & 3,06 & 1,31 & 1,72 & 12,55 & 0,82 \\
\hline 2 & $\begin{array}{l}\text { I like spending money on many different } \\
\text { things (C) }\end{array}$ & 217 & 1 & 5 & 4,00 & 3,53 & 1,25 & 1,56 & 12,71 & 0,82 \\
\hline 3 & $\begin{array}{l}\text { My life would be better if I owned many of } \\
\text { the things I don't have }(\mathrm{H})\end{array}$ & 217 & 1 & 5 & 4,00 & 3,47 & 1,35 & 1,82 & 12,45 & 0,83 \\
\hline 4 & $\begin{array}{l}\text { Buying things gives me a lot of pleasure } \\
\text { (C) }\end{array}$ & 217 & 1 & 5 & 4,00 & 3,75 & 1,16 & 1,35 & 12,92 & 0,82 \\
\hline 5 & $\begin{array}{l}\text { I'd be happier if I could afford to buy more } \\
\text { things }(\mathrm{H})\end{array}$ & 217 & 1 & 5 & 4,00 & 3,94 & 1,13 & 1,28 & 12,99 & 0,81 \\
\hline 6 & I like to own things that impress people (S) & 217 & 1 & 5 & 2,00 & 2,47 & 1,14 & 1,30 & 12,97 & 0,81 \\
\hline 7 & I like a lot of luxury in my life (C) & 217 & 1 & 5 & 3,00 & 3,12 & 1,35 & 1,82 & 12,45 & 0,83 \\
\hline 8 & $\begin{array}{l}\text { It bothers me that I can't afford to buy all } \\
\text { the things I like }(\mathrm{H})\end{array}$ & 217 & 1 & 5 & 4,00 & 3,62 & 1,21 & 1,46 & 12,81 & 0,82 \\
\hline \multirow[t]{2}{*}{9} & $\begin{array}{l}\text { Some of the most important achievements } \\
\text { in life include acquiring material } \\
\text { possessions (S) }\end{array}$ & 217 & 1 & 5 & 3,00 & 2,97 & 1,40 & 1,96 & 12,31 & 0,83 \\
\hline & Total Materialism Score & & & & & 29,93 & 6,86 & 47,06 & & \\
\hline
\end{tabular}

(S) Part of success subscale

(C) Part of centrality subscale

(H) Part of happiness subscale 
Based on the results presented in Table 8, the following observations regarding mean materialism scores are made:

- Only two of the nine items presented achieved a mean score below 3. In general therefore respondents tended to agree with the statements made. This observation lends to support a view that the consumers sampled displayed strong characteristics of materialism.

- $\quad$ The lowest scoring statement was item 6, "I like to own things that impress people." A low score for this statement, which is linked to the success subscale, is indicative that the consumers sampled are not strongly motivated by status when they acquire their possessions.

- $\quad$ The statement for which the highest mean score was obtained was item 5, "I'd be happier if I could afford to buy more things". A high score for this statement, which is linked to the happiness subscale, could suggest one of two things. First, it suggests that for the consumers sampled their current income levels are a constraint to them acquiring all of the things they desire. Second it suggests that achieving happiness or personal fulfilment is a strong motivator when selecting which items to acquire.

In this sample the standard deviations calculated ranged between 1.13 and 1.40, with the following observations being regarded as relevant:

- $\quad$ The item for which the highest standard deviation was recorded was item 9, "Some of the most important achievements in life include acquiring material possessions". One possible interpretation of this result is that this was the item on which respondents had the most conflicting views. Another explanation, however, might be that this is the statement that respondents had greatest difficulty understanding and therefore different interpretations of the statement led to varying scores being assigned.

- $\quad$ The item for which the lowest standard deviation was recorded was item 5, "I'd be happier if I could afford to buy more things". The low standard deviation suggests that respondents consistently agreed with this particular statement.

- $\quad$ Read together with the mean scores, it is important to note that item 6, which had the lowest mean score, also had a relatively low standard deviation (1.16). Respondents were therefore consistent in their view that achieving success was not a primary motivator in their buying behaviour.

The final column in Table 8 depicts the results of tests performed to test the reliability of the scale. Using Cronbach's alpha, the average reliability coefficient for the scale was calculated as 0.82 , a fairly high alpha score which by all standards can be considered to be good. There is therefore strong evidence to suggest that the materialism scale used in this study has produced reliable results.

Earlier reference was made to the materialism subscales of happiness, success and centrality. The 9-item materialism scale used in this study included three statements respectively for each of the aforementioned subscales. The materialism scale results presented above could therefore be further stratified into three subscales of three items each. The summated results of the three items in each of these three subscales were calculated and are presented in Table 9.

Table 9: Summary of materialism subscale scores

\begin{tabular}{|c|c|c|c|c|c|}
\hline Description & Count & Min & Max & Mean & Std Dev \\
\hline Success & 217 & 3 & 15 & 8,49 & 3,02 \\
\hline Centrality & 217 & 3 & 15 & 10,40 & 2,65 \\
\hline Happiness & 217 & 3 & 15 & 11,03 & 2,77 \\
\hline
\end{tabular}

The subscales mentioned here are aligned to the Richins and Dawson's (1992) value based definition of materialism. Based on this definition materialistic behaviour is motivated by three key values - acquisition centrality, acquisition as the pursuit of happiness and possession-defined success. Table 9 shows the summated mean scores and standard deviations for each of these three subscales. Ranked from lowest to highest mean score, the table shows success to be the least important materialistic value for this particular sample; followed by centrality and then happiness. Applying the meanings intended by Richins and Dawson (1992:304), the sampled HomeChoice consumers are therefore most likely to view their possessions and acquisitions "as being essential to their satisfaction and well being" but least likely to "judge their own and others' success by the number and quality of possessions accumulated".

Using ANOVA techniques and Tukey multiple comparison methods it is possible to conclude that the differences between the means of the materialism subscale scores are significant. In particular, Tukey testing shows that success, as a materialism value, is significantly less important than happiness and centrality to the sampled HomeChoice consumers (all tests performed at the 5\% level).

This interpretation is of most relevance when viewed in relation to previous studies. The results for this sample for example are very different from studies in which an Asian sample was examined, where success was consistently 
found to be the most important materialistic value (Webster \& Beatty, 1997; Eastman et al., 1997). Studies that produced similar results, however, were those performed by Griffen et al. (2004) and Ponchio and Aranha (2008), who tested the materialism scale with samples from Russia and Brazil respectively. The significance of this finding will be further discussed in Section 5.
In the previous chapter it was highlighted that one of the benefits of using the same survey statements as was used by Ponchio and Aranha (2008) is that the results of this study can be compared to the results obtained by these researchers in the study they performed in Sao Paolo, Brazil.

Table 10 provides a summary of the achieved materialism scores for this study and the Brazilian study.

Table 10: Summary of materialism scores - Brazil and South Africa

\begin{tabular}{|c|c|c|c|c|c|c|c|}
\hline \multirow[b]{3}{*}{ Item } & \multirow[b]{3}{*}{ Description } & \multirow{2}{*}{\multicolumn{3}{|c|}{ Brazil }} & \multirow{2}{*}{\multicolumn{3}{|c|}{ South Africa }} \\
\hline & & & & & & & \\
\hline & & $\mathrm{N}$ & Mean & Std Dev & $\mathrm{N}$ & Mean & Std Dev \\
\hline 1 & $\begin{array}{l}\text { I admire people who own expensive homes, cars and } \\
\text { clothes (S) }\end{array}$ & 436 & 2,59 & 1,53 & 217 & 3,06 & 1,31 \\
\hline 2 & I like spending money on many different things (C) & 436 & 1,71 & 1,23 & 217 & 3,53 & 1,25 \\
\hline 3 & $\begin{array}{l}\text { My life would be better if I owned many of the things I } \\
\text { don't have }(H)\end{array}$ & 436 & 3,76 & 1,47 & 217 & 3,47 & 1,35 \\
\hline 4 & Buying things gives me a lot of pleasure (C) & 436 & 3,26 & 1,55 & 217 & 3,75 & 1,16 \\
\hline 5 & I'd be happier if I could afford to buy more things $(\mathrm{H})$ & 436 & 4,11 & 1,26 & 217 & 3,94 & 1,13 \\
\hline 6 & I like to own things that impress people (S) & 436 & 1,67 & 1,28 & 217 & 2,47 & 1,14 \\
\hline 7 & I like a lot of luxury in my life (C) & 436 & 1,79 & 1,24 & 217 & 3,12 & 1,35 \\
\hline 8 & $\begin{array}{l}\text { It bothers me that I can't afford to buy all the things I } \\
\text { like }(\mathrm{H})\end{array}$ & 436 & 3,18 & 1,54 & 217 & 3,62 & 1,21 \\
\hline \multirow[t]{2}{*}{9} & $\begin{array}{l}\text { Some of the most important achievements in life } \\
\text { include acquiring material possessions (S) }\end{array}$ & 436 & 1,75 & 1,30 & 217 & 2,97 & 1,40 \\
\hline & Total Materialism Score & 436 & 23,81 & 7,03 & 217 & 29,93 & 6,86 \\
\hline
\end{tabular}

Source: Brazilian data adapted from Ponchio and Aranha (2008:27)

Based on the results depicted in Table 10, the following observations regarding the nine materialism statements can be made:

- $\quad$ Observed mean scores for the Brazilian study range from 1.67 to 4.11 , while for the South African study this range is only 2.47 to 3.94 . Thus, although the measurement scales for both studies are the same, the observed means for the Brazilian study have a far broader range than the observed means for the South African study.

- Standard deviations for the Brazilian study ranged from 1.23 to 1.55 , while for the South African study this range was only 1.13 to 1.40 . Thus there was greater variability in the responses received from respondents in the Brazilian sample than in the South African sample.

- The highest mean scores for both studies was attained for question 5 'I'd be happier if I could afford to buy more things'.

While the mean materialism scores for the Brazilian study are generally found to be lower than for the South African study, the information provided in Table 10 is not sufficient to conclude that levels of materialism amongst the sampled HomeChoice consumers are significantly different from the levels of materialism observed in Brazil. However, the results of the t-test, indicate that at an aggregated level, mean South African scores are significantly higher than in Brazil $(\alpha=0,05)$.
The findings of previous studies suggest that the characteristics that define a transitional economy, which include new freedom to acquire desired goods and a general shift towards capitalistic economic systems, are also the characteristics that are most often associated with high levels of materialism. Given that the results of this study have shown South African low-income consumers to be highly materialistic, it is not implausible to assume that it is the very transition from apartheid to democracy that has led to the increased levels of consumption and indebtedness in recent years. Based on the nature of testing performed in this study however, such findings are merely suggestive rather than conclusive.

If this assumption is true, however, we would expect that other transitional economies would experience similar levels of materialism as is experienced in the South African economy. To test this assumption we consider the results of the materialism study performed by Griffen et al. (2004) which included a Russian sample.

To assess whether the high levels of materialism found in the Russian sample is comparable to the South African sample used in this study, comparative statistics on the materialism scores for each country was calculated, using the same approach followed when comparing the materialism scores of South African and Brazil. The results of this comparison are shown in Table 11. 
Table 11: Summary of materialism scores - Russia and South Africa

\begin{tabular}{|c|c|c|c|c|c|c|c|}
\hline \multirow[b]{3}{*}{ Item } & \multirow[b]{3}{*}{ Description } & \multirow{2}{*}{\multicolumn{3}{|c|}{ Russia }} & \multirow{2}{*}{\multicolumn{3}{|c|}{ South Africa }} \\
\hline & & & & & & & \\
\hline & & $\mathrm{N}$ & Mean & Std Dev & $\mathrm{N}$ & Mean & Std Dev \\
\hline 1 & $\begin{array}{l}\text { I admire people who own expensive homes, cars and } \\
\text { clothes (S) }\end{array}$ & 103 & 2,88 & 1,16 & 217 & 3,06 & 1,31 \\
\hline 2 & I like spending money on many different things (C) & 103 & 2,64 & 0,99 & 217 & 3,53 & 1,25 \\
\hline 3 & $\begin{array}{l}\text { My life would be better if I owned many of the things I } \\
\text { don't have }(\mathrm{H})\end{array}$ & 103 & 3,70 & 0,84 & 217 & 3,47 & 1,35 \\
\hline 4 & Buying things gives me a lot of pleasure $(\mathrm{C})$ & 103 & 3,69 & 0,91 & 217 & 3,75 & 1,16 \\
\hline 5 & I'd be happier if I could afford to buy more things $(\mathrm{H})$ & 103 & 3,43 & 1,00 & 217 & 3,94 & 1,13 \\
\hline 6 & I like to own things that impress people (S) & 103 & 3,81 & 0,96 & 217 & 2,47 & 1,14 \\
\hline 7 & I like a lot of luxury in my life $(\mathrm{C})$ & 103 & 3,48 & 1,13 & 217 & 3,12 & 1,35 \\
\hline 8 & $\begin{array}{l}\text { It bothers me that I can't afford to buy all the things I } \\
\text { like }(\mathrm{H})\end{array}$ & 103 & 3,28 & 1,15 & 217 & 3,62 & 1,21 \\
\hline \multirow[t]{2}{*}{9} & $\begin{array}{l}\text { Some of the most important achievements in life } \\
\text { include acquiring material possessions (S) }\end{array}$ & 103 & 2,51 & 1,02 & 217 & 2,97 & 1,40 \\
\hline & Total Materialism Score & 103 & 29,42 & $7,00^{\wedge}$ & 217 & 29,93 & 6,86 \\
\hline
\end{tabular}

(S) Part of success subscale

(C) Part of centrality subscale

(H) Part of happiness subscale

$\wedge$ The study by Griffen et al (2004) used the original 18 item Richins and Dawson (1992) MVS Based on previous studies, a 9-item standard deviation of 700 was assumed for the Russian sample

Based on the results depicted in Table 11, the following observations can be made:

- The observed means scores for the Russian study are almost always lower than the scores provided by the South African sample, with the only exceptions being items 3,6 and 7.

- Regarding items 6 and 7, Russians tend to display stronger desires to own things that impress people and want more luxury in their lives than the South Africans did, both items suggesting that South Africans are less likely to be motivated by greed than their Russian counterparts.

- Standard deviations in mean responses for the Russian sample are consistently lower than observed standard deviations for the South African sample suggesting that the respondents in Russia were more uniform in their responses than the South African respondents were.

At the aggregated mean materialism level, the mean materialism scores for the Russian sample appear to be very similar to the materialism levels of sampled HomeChoice consumers. As a final assessment, the t-test is used to statistically compare the means of these two populations. The results of the t-test show that the scores for the Russian sample were not significantly ( $\alpha=0,05)$ different from the scores observed for the South African sample. The two samples therefore display relatively equal levels of materialism. Again, while the results here are not conclusive, they do seem to suggest that being a transitional economy can influence the level of materialism of that economy's consumers.

At a next level we investigate whether the mean levels of materialism of consumers sampled vary with changes in age, gender or levels of income. These three demographic characteristics were chosen for further analysis because previous studies (Belk, 1985; Ger \& Belk, 1990; Micken, 1995; Fitzmaurice \& Comegys, 2006; Lerman \& Maxwell, 2006; Ponchio \& Aranha, 2008) have consistently linked them to materialism level differentials.

The key descriptive statistics and results of the ANOVA testing performed are presented in Table 12. 
Table 12: ANOVA Test - Differences in mean levels of materialism for selected demographic variables

\begin{tabular}{|c|c|c|c|c|c|c|c|c|}
\hline Variable & Count & $\%$ & $\begin{array}{l}\text { Source of } \\
\text { variation }\end{array}$ & $\begin{array}{l}\text { Sum of } \\
\text { squares }\end{array}$ & $\mathrm{df}$ & $\begin{array}{l}\text { Mean } \\
\text { square }\end{array}$ & $\mathrm{F}$ & P-value \\
\hline
\end{tabular}

\begin{tabular}{|c|c|c|c|c|c|c|c|c|c|}
\hline \multicolumn{10}{|l|}{ Age: } \\
\hline Between 22 and 24 & 10 & $4,61 \%$ & 27,50 & \begin{tabular}{|l|} 
Between \\
groups
\end{tabular} & 802,81 & 3 & 2674,61 & 6,09 & $0,001 *$ \\
\hline Between 25 and 34 & 69 & $31,80 \%$ & 31,70 & $\begin{array}{l}\text { Within } \\
\text { groups }\end{array}$ & 9360,00 & 213 & 43,94 & & \\
\hline Between 35 and 49 & 91 & $41,94 \%$ & 30,53 & Total & 10162,82 & 216 & & & \\
\hline Over 50 & 47 & $21,66 \%$ & 26,68 & & & & & & \\
\hline
\end{tabular}

\begin{tabular}{|c|c|c|c|c|c|c|c|c|c|}
\hline \multicolumn{10}{|l|}{ Gender: } \\
\hline Male & 44 & $20,28 \%$ & 30,55 & \begin{tabular}{|l|} 
Between \\
groups
\end{tabular} & 21,16 & 1 & 21,16 & 0,45 & $\begin{array}{c}0,504 \\
(\mathrm{~ns})\end{array}$ \\
\hline \multirow[t]{2}{*}{ Female } & 173 & $79,72 \%$ & 29,77 & $\begin{array}{l}\text { Within } \\
\text { groups }\end{array}$ & 10141,66 & 215 & 47,17 & & \\
\hline & & & & Total & 10162,82 & 216 & & & \\
\hline
\end{tabular}

\begin{tabular}{|c|c|c|c|c|c|c|c|c|c|}
\hline \multicolumn{10}{|l|}{ Monthly income: } \\
\hline From R 500 to R 2000 & 86 & $39,63 \%$ & 29,31 & $\begin{array}{l}\text { Between } \\
\text { groups }\end{array}$ & 65,26 & 3 & 21,75 & 0,46 & $\begin{array}{c}0,711 \\
\text { (ns) }\end{array}$ \\
\hline From R 2001 to R 3000 & 39 & $17,97 \%$ & 30,51 & \begin{tabular}{|l|}
$\begin{array}{l}\text { Within } \\
\text { groups }\end{array}$ \\
\end{tabular} & 10097,57 & 213 & 47,41 & & \\
\hline From R 3001 to R 4000 & 40 & $18,43 \%$ & 30,63 & Total & 10162,82 & 216 & & & \\
\hline From R 4001 to R 7000 & 52 & $23,96 \%$ & 29,96 & & & & & & \\
\hline
\end{tabular}

* Significant at the 0,05 level

(ns) not significant

The data seems to support Lerman and Maxwell's (2006) observations, with levels of materialism being lowest for the "over 50" age group. ANOVA testing also confirm that at a $5 \%$ significance level, statistically significant differences do exist in mean levels of materialism depending on the respondent's age.

To better understand the age related factors that account for the differences in mean levels of materialism Tukey's multiple comparison methods have been utilised. The results suggest that levels of materialism are only significantly different for age groups 2 and 4 i.e. the levels of materialism, for respondents aged between 25 and 34 is significantly higher than for those respondents aged over 50, a finding that is consistent with previous studies which explored relationship between age and materialism.

There is only a very small difference in the mean levels of materialism between female and male respondents, which ANOVA testing supported as being non-insignificant at a $5 \%$ significance level.

Mean levels of materialism are also very similar across different income levels and ANOVA testing finds no significant difference between mean levels of materialism for respondents in different income brackets.

\section{Indebtedness}

Levels of indebtedness can be measured in many ways. Watson (1998) for example measured the absolute value of indebtedness. The weakness in this approach, as identified by Watson (1998) and Collins (2008) is that in a single contact survey this once off measure at a point in time often does not capture the individual's true propensity to incur debt. Other measures, like the ratios used by the SARB, are useful when measured and compared over numerous time periods. They are however, more appropriately used when viewed in aggregate than for individual consumers.

To measure levels of indebtedness in this study, respondents were instead asked to indicate the number of retail store accounts they held. The survey responses showed that the number of store accounts held by HomeChoice customers ranged between 1 account and 8 accounts. The distribution of number of accounts held is depicted in Figure 1.

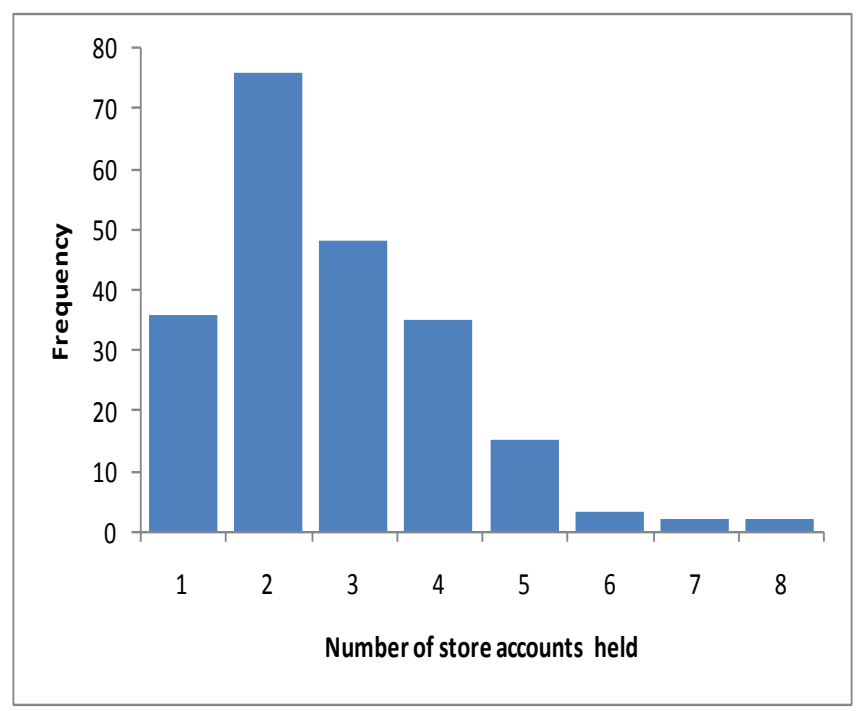

Figure 1: Histogram of levels of indebtedness 
Based on the results depicted in Figure 1, the following observations can be made:

- While the range in the number of store accounts held is fairly wide, the distribution of accounts held is strongly skewed to the right, with most respondents holding less than 4 store accounts and the mean number of accounts held being only 2.74 .

- $\quad$ There were only 7 respondents who reported having more than five store accounts. This number is not surprising, given the relatively low income levels of the respondents. It should be noted that with a reduced income comes a diminished ability to meet one's commitments. What is unclear in the results however is whether the low number of respondents having large numbers of accounts is due to restrictions on the part of credit providers or self-control on the part of the respondents.

- $\quad$ Respondents most frequently indicated that they held only two store accounts. Given the recent increase in levels of indebtedness, across all income groups, this measure is surprisingly low.

- $\quad$ Seventeen percent of customers reported having only one account - a HomeChoice account. This result appears to be indicative of a lack of credit access.

\section{Correlation analysis}

The next objective is to determine whether any significant relationships exist between (i) the respondents' levels of indebtedness and their levels of materialism and (ii) the respondents' levels of indebtedness and certain key demographic variables like age, gender and income. If these relationships do exist, the secondary objective is to describe these relationships. Using more appropriate terminology, the first objective seeks to determine the presence of a relationship while the second objective considers the nature of the relationship.

Table 13 presents the results of a correlation analysis testing whether respondents' levels of indebtedness was significantly linked to respondents' levels of materialism, income, gender and age.

\section{Table 13: Test for linear association}

\begin{tabular}{lccc}
\multicolumn{1}{c}{ Variables tested } & $\begin{array}{c}\text { Coefficient } \\
\text { of } \\
\text { correlation }\end{array}$ & t-Stat & $\begin{array}{c}\text { Significance } \\
\text { (two tailed) }\end{array}$ \\
\hline Materialism and indebtedness & 0,08 & 1,24 & $0,2164(\mathrm{~ns})$ \\
Income and indebtedness & 0,13 & 1,98 & $0,049 *$ \\
Gender and indebtedness & 0,16 & 2,44 & $0,016 *$ \\
Age and indebtedness & $-0,19$ & $-2,83$ & $0,005 *$ \\
\hline
\end{tabular}

* Significant at the 0.05 level

(ns) not significant
A number of conclusions can be drawn:

- For three of the four variable pairs being tested, the results are found to be significant at the 5\% level. This is despite the relatively low correlation coefficients for these variable pairs.

- The relationship found to be non-significant was the relationship between materialism and indebtedness.

- The relationship between income and indebtedness is marginally significant at a $5 \%$ level. Intuitively it is expected that an increase in income should result in an increase in credit access. The general level of income of respondents in this study might still be too low however to expect significant differentiation in credit access.

- Gender and indebtedness are significantly and positively related at the $5 \%$ significance level, implying that males demonstrate higher levels of indebtedness than females. This, however, may be ascribed to the fact that males have easier access to credit than females.

- $\quad$ The most significant relationship $(\alpha=0,005)$ appears to be between age and indebtedness. More notably it is the only instance where a negative relationship exists between the two relevant variables.

The results of the test for linear association therefore suggest that linear relationships exist between indebtedness and all three of the key demographic variables of income, gender and age. A linear relationship was not found between indebtedness and materialism, but the fact that a non-linear relationship may exist was not precluded.

In order to better understand the relationship between indebtedness and the four explanatory variables discussed a regression model was developed in which respondents' levels of indebtedness was the dependent variable and age, gender, income and materialism were the independent variables. The computer software was then used to generate the coefficients and statistics used to analysis the model. Table 14 presents the results.

A detailed assessment of the results presented in Table 14 revealed a number of concerns in the model which should be highlighted:

- The regression statistics show a coefficient of determination or $R^{2}$ of $8.03 \%$. This is indicative of the fact that the model does not provide a particularly good fit. 
Table 14: Multiple regression analysis: Excel summary output

\begin{tabular}{lc}
\hline & Regression Statistics \\
\hline Multiple R & $28,338 \%$ \\
R Square & $8,030 \%$ \\
Adjusted R Square & $6,295 \%$ \\
Standard Error & 1,333 \\
Observations & 217 \\
\hline
\end{tabular}

ANOVA

\begin{tabular}{lrlrrr} 
& $d f$ & & SS & MS & F \\
\hline Regression & 4 & 32,888 & 8,222 & 4,628 & \\
Residual & 212 & 376,661 & 1,777 & & \\
Total & 216 & 409,548 & & & \\
\hline
\end{tabular}

\begin{tabular}{llllr}
\hline & & & & \\
& Coefficients & Standard Error & t-stat & $P$-value \\
\hline Intercept & 2,364 & 0,605 & 3,908 & $0,000^{*}$ \\
Age & $(0,017)$ & 0,007 & $(2,479)$ & $0,014^{*}$ \\
Gender & 0,574 & 0,226 & 2,542 & $0,012^{*}$ \\
Income & 0,000 & 0,000 & 1,887 & $0,061(\mathrm{~ns})$ \\
Materialism & 0,011 & 0,013 & 0,789 & $0,430(\mathrm{~ns})$ \\
\hline
\end{tabular}

* Significant at the 0.05 level

(ns) not significant

- The regression statistics also reports a standard error of 1.33. In assessing the fit of the model, it is the relative rather than the absolute value of the error which is important. More specifically the magnitude of the standard error in generally judged in relation to the mean value of the dependent variable, in this case the mean level of indebtedness of the respondents. In this study the mean level of indebtedness of respondents was found to be 2.74 . Relative to a value of 2.74 a standard error of 1.33 is very large, providing a further indication that the model is not a good fit.

- If the F-statistic is large, there is evidence to infer that the model is valid. In this model the F-statistic is 4.63 , which is large enough to be significant at the $1 \%$ significance level and therefore large enough to infer that the model is valid.

- As concluded from the correlation analysis, of the four independent variables included in the model only two, age and gender, were significant.

- Age was the only variable found to be negatively related to levels of indebtedness.

- The results clearly indicate that the inclusion of income and materialism as independent variables are not significant and therefore in no way enhances the fit or validity of the model.
- The coefficient value for income was in fact 0.00 indicating that income for the low-income consumer does not have any predictive value in determining levels of indebtedness.

Stepwise regression techniques were also used. Stepwise regression differs from standard multiple regression in that it does not assume that all independent variable are related to the dependent variable. Instead, the stepwise regression technique introduces one independent variable into the model at a time and only includes variables that ultimately improve the fit of the model.

Using stepwise regression techniques, the final regression equation still includes only age and gender as significant variables, a result that is in line with the earlier correlation analysis results.

\section{Interpretation and conclusion}

The materialism scores achieved in this study clearly show that HomeChoice consumers' buying decisions are motivated by whether the acquisition or the ultimate possession of that item would bring them happiness. This finding raises the question of whether the availability of money, which enables low-income consumers - like those sampled in this study - to buy more of the material things they desire, can really buy happiness.

There is a significant body of literature that discusses the relationship between materialism and happiness. Many allude to anecdotal evidence of increases in money and 
consumption leading to improved life satisfaction or wellbeing. Ger and Belk (1990: 186), for example, remind us that "consumption for the sake of pleasure existed in many different cultures and throughout history". This view is often reinforced by historians in their depictions of lavish feasts in ancient Roman or Victorian times or their portrayals of opulence in the courts of the Tzars and Emperors of the East.

Belk (1984: 291) believed that possessions have the ability to influence our sense of well-being. He discussed the notion that for the materialistic individual, possessions were of such centrality to their lives that the absence of such possessions might lead to dissatisfaction. Richins (1987: 352) also found a positive link between materialism and overall life satisfaction. In particular, Richins (1987: 352) remarked that the media, which often screen advertisements that link products to happy people, bolster the common view that consumption is necessary for living the good life. Richins and Dawson (1992) believed consumption and happiness to be so closely related that it formed a key value when they developed the material values scale; a value they described as 'acquisition as the pursuit of happiness'.

Cultural and societal norms further reinforce the notion that money should lead to happiness. Burroughs and Rindfleish (2002: 348) comment that "consumption (has become) a culturally accepted means of seeking success and happiness", while Tatzel (2003: 406) admonishes the societal beliefs that "hold out images of a consumer paradise" and that "defines success by material achievement".

Yet despite the widely held belief that money and consumption should bring happiness, empirical evidence often finds a negative relationship between these variables. In Belk's (1984) initial development of the trait based materialism scale, traits of "envy and non-generosity ... (were) found to be negatively related to reported happiness with life". Richins (1987: 353) also discussed how, for the highly materialistic individual, possessions may become unfulfilling as "larger and larger doses (of material acquisitions are needed) to maintain happiness". Burroughs and Rindfleisch (2002: 348) reported that highly materialistic people routinely "exhibit reduced life satisfaction, diminished levels of happiness and higher levels of depression". Tatzel (2003: 427) finds that the endless pursuit for material things often leaves those with high levels of materialism feeling frustrated and dissatisfied. Finally Von Boven (2005: 133) observed that increased possessions "produces virtually no measurable gains in our psychological or physical well-being".

Given the seemingly overwhelming empirical evidence suggesting that money and consumption do not lead to happiness why is it, in the sample of consumers surveyed, that the view that the ability to buy more things will bring happiness is so common-place?

In searching for a credible answer to this question it is vital to understand what sets this sample of consumers apart from other samples where negative relationships between materialism and happiness were found. The most distinguishing factors in this study are that the consumers all earn a relatively low income and due to apartheid all at some point experienced a level of exclusion or deprivation which now shape their views of money and consumption.

Regarding the influence of earning a relatively low income, Tatzel offers a very compelling perspective that "not having money accounts for a greater measure of unhappiness than having money accounts for happiness". For the individuals sampled in this study, this idea appears to have great merit. It cannot be ignored that when a lack of money is seen as the root cause of unhappiness in one's household, it is quite conceivable that an individual would hold the view that "I'd be happier if I could afford to buy more things". It is therefore probably not a coincidence that for this study, it is this very statement within the materialism scale that respondents agreed with most strongly.

In a relatively poor household, feelings of unhappiness can stem from the lack of financial means to meet basic needs. These basic needs often include the need for tangible items like food, water or medicines, but these needs may also be intangible. Sangkhawasi and Johri (2007: 278), in their study on materialism in Thailand, observed that Thais displayed a basic need for "belongingness to society". This view is not dissimilar to insights offered by Sawady and Teschner (2008), who observed that amongst low-income consumers the decision to acquire a possession is often based on whether that acquisition will appease their sense of belonging.

Regarding the influence of relative deprivation, it should be noted that this is a subject that often arises in studies that address materialism in developing economies and in studies that deal with income inequality. Ger and Belk (1996: 58), for example, introduced the notion that individuals in the "less economically developed countries ... feel a keener sense of relative deprivation." Tatzel (2003: 413) also believed that "early economic deprivation" later heightens that individual's focus on material needs.

To fully grasp the idea of relative deprivation it is important to understand relative to whom an individual is regarded as being deprived. Kingdon and Knight (2007), in a study on subjective well-being in South Africa, found race to be important factor in social comparison. More specifically, they found that individuals' "...aspirations are linked to what they believed to be the range of states attainable for persons of their own race (Kingdon \& Knight, 2007: 73)". This finding affirms the role played by reference groups in stimulating material desire.

Kingdon and Knight (2007: 70) also observed that an individual can have "more than one comparator group" and while they might feel deprived within the larger society, when judged within their own community they might be regarded as privileged. Tatzel (2003: 411) supports this view, finding that it is relative rather than absolute income that "seems to matter for well-being". Thus within a more localised, community setting it is possible that even very small increases in income can lead to increased happiness if it means that the individual's level of income moves from 
being below the average level of wealth within that community to being above the average.

Ultimately, therefore, it would appear that amongst South Africa's low-income consumers money really can buy happiness.

One of the relative unknowns in our understanding of South African low-income consumer behaviour is whether the very transition from apartheid to democracy might be a primary motivation for consumers to now spend more and to incur more debt. This part of the chapter considers whether being a transitional economy influences levels of materialism, and consequently levels of consumption and indebtedness amongst South African low-income consumers.

Tambyah, Mai and Jung (2009:176) defines a transitional economy as one "that moves from a planned economy, where consumption was prescribed, to a market economy where consumers have the freedom to satisfy their acquisition fantasies". While the South African apartheid regime might not have been a "planned economy" as envisaged by these writers, for South African black lowincome consumers the restrictions that apartheid policies imposed on their basic liberties, including where and how they could consume, meant that life after apartheid would most certainly have been characterised by a new-found "freedom to satisfy their acquisition fantasies". This new freedom would have been fuelled not only by renewed access, in terms of consumption and credit, but also by improved choice with foreign companies re-entering the South African market and exposing the country again to more Western ideals and lifestyles.

A key hallmark of South Africa's transition to democracy was that despite the new ruling political party's leanings towards leftist policies, to encourage foreign investment the country's post-apartheid government often promoted more capitalist economic policies. This is particularly relevant given research by Kasser and Sheldon (2000, 350) who found that "capitalist economic systems" are more likely to foster a "culture of consumption."

Even in the absence of a capitalist economic system, Kasser and Sheldon $(2000,348)$ note that conditions of poverty "are (often) associated with a strong focus on materialistic values". In the South African context, these strong materialistic values are further intensified by significant levels of income inequality, which in this country have actually increased post-apartheid. As observed by Ger and Belk (1990: 191) such increasing levels of inequality in income creates a sense of relative deprivation that can only serve to increase the desire of low-income individuals, the relative poor, to consume.

Comparing Russia with South African data (see Section 4) the results do suggest that being in a transitional economy can have an influence on the level of materialism.

The factors that affect the financial management decisions of low-income consumers need discussion because we have to understand why, when the literature commonly portrays debt as a welcome instrument to "satisfy acquisitive desire"
(Watson, 1998:203), the results of regression analysis testing in Section 4 clearly shows that materialism is not a significant variable in predicting HomeChoice consumers' propensity for incurring debt.

Previous research on materialism and indebtedness reached varying conclusions on whether materialism was in fact a significant predictor in models of indebtedness. Using a sample of students from New Zealand, Watson (1998) found that while highly materialist people have more favourable attitudes towards debt, the data did not identify materialism to be an important predictor of levels of debt. In later research, Watson (2003) performed a similar study, this time using a sample to adult consumers from the United States. The results of this study again showed that highly materialistic people have more favourable attitudes towards debt, but also found that these individuals were "more likely to use instalment credit and have loans in excess of $\$ 1,000$ " (Watson, 2003:735). Ponchio and Aranha (2008) on the other hand, using a sample of low-income consumers from Brazil, observed a significant relationship between materialism and indebtedness. They found that "the materialism effect is such that it nearly doubles the probability of possession of (an instalment) booklet" (Ponchio \& Aranha, 2008:31).

When comparing the results of this study to the results of previous studies, where the relationship between materialism and indebtedness has been explored, the inescapable question that arises is: 'What is unique about the behaviour of consumers sampled in this study that might explain the difference in observed results?'. This question is particularly perplexing when comparing the conclusions reached in this study to the findings of Ponchio and Aranha (2008) where the sampled individuals were also low-income consumers who reportedly experienced similar levels of "budget restrictions and difficulty in accessing financial services" as is commonly reported for low-income consumers in this country. When evaluating these two countries, many of the key demographic and economic factors are very similar - like access to education and levels of income inequality - yet these countries' attitudes towards debt and consumption are seemingly very different. Two relevant differences between Brazil and South Africa are mainstream exclusion and levels of unemployment.

In the South African context mainstream exclusion alludes to the impact that exclusionist apartheid policies has had on low-income consumers' attitudes towards debt today. To explain the impact of mainstream exclusion, consider the fact that during the apartheid years many individuals were denied access to formal credit on the basis of race rather than creditworthiness. Without access to formal sector credit these consumers sought credit from informal sources usually friends or relatives. Using informal credit sources these consumers were able to meet their basic consumption needs during apartheid years. Once apartheid rules were abolished therefore, though access to formal credit might have improved, due to the continued availability of informal credit many of these individuals choose not to access formal credit. 
This is evident in many of the South African studies on indebtedness (Daniels, 2001; Hurwitz \& Luiz, 2007; Collins, 2008). Hurwitz and Luiz (2007: 112) for example reports that by 2003 " $72 \%$ of credit (in the formal sector) was extended to about $15 \%$ of the population" while lowincome consumers, representing roughly $67 \%$ of the population still "enjoyed only $6 \%$ of the total credit granted."

Another view regarding mainstream exclusion, offered by Sawady and Teschner (2008: 97) is that "decades of exclusion from the mainstream ... engender deep mistrust of mainstream practices". In their view low-income consumers are often sceptical of the practices of formal credit providers. In this regard the imposition of minimum income requirements, monthly fees and the practice of blacklisting customers who fall behind on instalments all contribute to feelings of mistrust.

Brazilians, having not been exposed to mainstream exclusion of this nature are unlikely to have similar feelings of mistrust and therefore their attitudes towards debt may differ markedly from South African attitudes towards debt.

Regarding unemployment, the levels of unemployment in Brazil is reported by the World Bank (2007: 56) to be roughly $10 \%$. In South Africa this figure is closer to $27 \%$ (World Bank, 2007: 58). In addition, the incidence of informal sector employment is far more common in South Africa than in Brazil. Sources of income for low-income South Africans are therefore often erratic and as a result these consumers tend to incur debt out of necessity rather than choice.

Hurwitz and Luiz (2007:128) reported, in a study they performed on indebtedness, that " $80 \%$ of the sample believed debt is an unavoidable reality that one can never escape." Moreover low-income households are known to "incur debt to smooth consumption ... before using it as a basis for asset accumulation" (Daniels, 2001: 3). South African low-income consumers are therefore more likely to incur a few small and affordable debts to "tide them over" rather than incur large debts simply to fund materialistic indulgence. Thus while Ponchio and Aranha (2008: 31) may report that low-income Brazilian consumers struggle to access credit, their relative stability in income is likely to improve the likelihood of a low-income earning Brazilian obtaining credit when compared to a low-income earning South African who has neither the security of income nor the collateral to access finance from the formal sector.

An alternative argument for why the conclusions reached in this study differ from the results of previous studies might lie in the methodology of the study. In the two previous studies where materialism was found to be a significant predictor of indebtedness, the tests performed to measure levels of indebtedness included only binomial experiments. In the Watson (2003) study for example, respondents were simply asked whether they have or do not have loans of more than $\$ 1,000$, not to indicate the absolute value of their debts as was done in the earlier study performed by Watson (1998). Similarly, in the Ponchio and Aranha (2008) study, respondents were asked whether they have or do not have an instalment payment plan booklet, not to indicate the number of instalment payment plan booklets they own. In this study the sample of customers chosen already all had one retail store account, the one they held with HomeChoice, and therefore a distinction between consumers who held retail store accounts and those who did not was not possible.

Given the results of previous studies on low-income consumerism, a final question is whether indebtedness is an inherent attribute of low-income consumerism and whether, as Rutherford (1999) hypothesised, the poor are in fact "very active (and responsible) managers of their financial resources" (Hurwitz \& Luiz, 2007:112).

Amid a flood of reports and statistics suggesting that levels of indebtedness are steadily increasing amongst low-income consumers in this country, the idea that these individuals are good financial managers seems almost counter-intuitive. Evidence that contradicts the view that low-income consumers are good financial managers includes the following:

- In the study performed by Hurwitz and Luiz (2007: 119) $60 \%$ of respondents reported being committed to debt repayments in excess of the accepted level of $30 \%$ of gross monthly income. Of this $60 \%$ almost half reported being committed to pay debt instalments equal to more than $100 \%$ of their gross monthly income.

- Prahalad (2006: 11) reports that low-income consumers knowingly pay a premium for goods and services received. He suggests that in Dharavi, India the poor pay up to 25 times more than what the rich pay. Such premiums are also payable in South Africa's loan market, with short-term loans attracting up to 6 times more interest in the low-income markets than is paid by more affluent consumers - and this is in the formal sector where maximum interest rates are regulated.

Yet despite evidence to suggest that low-income consumers often over-commit themselves or pay more than they should for goods and services there are also positive indicators that suggest that these actions are not necessarily reckless.

Walker (1996: 802) for example found, that for households under financial strain "greater debt coincides with 'better' financial management". Fundamentally, the findings indicated that individuals were willing to incur short-term debt to meet unexpected expenditure shocks and did not view this debt as negatively impacting their financial position. In contrast, they felt they were able to better 'cope' with their financial constraints by using debt. Collins (2008: 478) also found that access to credit benefits low-income households to the extent that it "allows them to stretch their small incomes from month to month".

It should also be noted that a distinguishing feature of lowincome consumerism is that these individuals tend to base their consumption decisions on affordability rather than price. By way of illustration, a low-income consumer would rather pay R1,000 for an appliance which he / she can pay off in instalments over 6 months than buy that same 
appliance for R500 cash, because the instalment value is what they can afford. When one considers the limited resources that most low-income earners have access to, the ability to ultimately make a R1,000 purchase clearly requires careful financial management.

The management skills of low-income consumers are further illustrated by evidence from the micro-lending industry which found that "during Indonesia's 1997 crisis and Bolivia's recent banking crisis, loan repayments were actually healthier amongst micro finance clients than amongst traditional commercial bank clients" (Hurwitz \& Luiz, 2007: 111). Through using debt, the low-income consumer is therefore able to meet commitments in spite of external shocks.

Based on what we know about low-income consumerism therefore, it is very possible that being a low-income consumer is an even greater predictor of indebtedness than materialism.

\section{Future research}

While this study provides a number of important insights into low-income consumer behaviour, from a South African perspective there is still much that we need to learn. Globally, focus on the Prahalad's (2006) so-called "bottom of the pyramid" research, has raised awareness regarding both the size and the profitability of doing business in lowincome markets. In South Africa, this market is conservatively estimated to spend around $\$ 40$ billion per annum, that's roughly $14 \%$ of current national GDP (IFC, 2007:143). The high materialism scores observed in this study also serves to reinforce the idea that the low-income market in South Africa has a largely untapped desire to consume.

While businesses are obviously enticed by the possibility of profits, sceptics note that there is a very fine line between serving the poor and exploiting the poor. To avoid crossing this line, any business that hopes to successfully enter the low-income market must do so ethically and responsibly. To achieve this and still make a profit these businesses must have the ability to make informed business decisions, decisions that require a level of research that is sorely lacking in this country.

Prahalad (2006) alludes to many businesses who have tried to enter the low-income market but have failed because they have tried to sell to low-income consumers a simply repackaged version of what they sell to more affluent consumers. They are often not willing to invest in innovation and produce a product that is tailor-made for the low-income market. Arguably, far more research is needed to fully understand both the needs of low-income consumers and the challenges these consumers face in accessing basic products or services. In this country, such challenges include high illiteracy rates and relatively low urbanisation levels simple realities where research can help business understand how to sell products to those who cannot read or how to make basic services available in remote rural locations.
Also, while the study provides a clear indication that respondents are highly materialistic there are a number of questions that remain unanswered. One question, which was clearly identified as a limitation in this study, was the extent to which the nature of goods sold by HomeChoice influenced observed levels of materialism. Research that would be beneficial in this regard would be studies that examine the level of materialism of low-income consumers of other institutions - like banks or consumable goods retailers - to determine whether the nature of goods bought is itself an indicator of materialism.

Another question is whether being a transitional economy does in fact influence levels of materialism. While the research performed in this study does seem to suggest this, there is little conclusive empirical evidence, in this study or in previous research, to confirm this assertion. Our knowledge of materialism could therefore be enhanced by performing cross-national studies, which aim specifically to measure levels of materialism in other transitional economies. If being a transitional economy does influence materialism another interesting area of research would be whether the effects of being a transitional economy eventually 'wears off' i.e. as one moves further from the point of transition does one become less materialistic. Inglehart (1981) certainly believed this. Seneca (2002: 4-5) describes how in Inglehart's research he uses the term "postmaterialism" to allude to the phase in which one moves away from survivalist / lower-order needs to higher order needs like relationships and self-actualisation, as described by Maslow (1970).

Finally, the conclusions reached in this study clearly show that our understanding of indebtedness in this country remains imperfect. Not only did the research not find materialism to be a significant predictor of indebtedness, regression analysis showed that the variables that had been identified for this study was only able to explain about $8 \%$ of the variability in levels of indebtedness of the respondents.

\section{References}

Belk, R.W. 1984. 'Three scales to measure constructs related to materialism: Reliability, validity, and relationships to measures of happiness', Advances in Consumer Research, 11:291-297.

Belk, R. 1985. 'Trait aspects of living in a material world', Journal of Consumer Research, 12:265-280.

Boushey, H. \& Weller, C.E. 2008. 'Has growing inequality contributed to rising household economic distress?' Review of Political Economy, 20(1): 1-22.

Bryce, W. \& Olney, T.T. 1991. 'Gender differences in consumption aspirations - a cross-cultural appraisal', Social Behaviour and Personality, 19(4):237-253.

Bureau of Market Research (BMR). 2008. Personal income by province, population group, sex, age and income group, 2007 and 2008. Research Report 378. Pretoria, South Africa: University of South Africa. 
Bureau of Market Research (BMR). 2007. The changing market dynamics of South Africa, 1996 to 2010. Research Report 366. Pretoria, South Africa: University of South Africa.

Burgess, S. 2002. SA tribes: Who we are, how we live and what we want from life in the new South Africa. Claremont, South Africa: David Philip Publishers.

Burroughs, J.E. \& Rindfleish, A. 2002. 'Materialism and well-being: A conflicting values perspective', Journal of Consumer Research, 29(3): 348-370.

Campbell, D.T. 1969. 'Materialism'. In Measure of social attitudes. Robinson, J.P. \& Shaver, P.R. (Eds.). Ann Arbor, USA: Institute for Social Research, p.p. 651-652.

Cant, M., Brink, A. \& Brijball, S. 2006. Consumer behaviour. Cape Town, South Africa: Juta.

Churchill, G.A. 1979. 'Paradigm for developing better measures of marketing constructs', Journal of Marketing Research, 16: 64-73.

Collins, D. 2008. 'Debt and household finance: Evidence from the financial diaries', Development Southern Africa, 25(4): 469-479.

The Herald, 13 January: 2009. p7. 'Consumer debt a big concern'.

'Cronbach's Alpha'. 2009. Wikipedia. [online] URL: http://en.wikipedia.org/wiki/Cronbach's alpha/ Accessed 22 September 2009.

Daniels, R. 2001. Consumer indebtedness among urban South African households: A descriptive overview. Working paper No. 1/55, Development Policy Research Unit. Cape Town: University of Cape Town.

Davies, E. \& Lea, S.E.G. 1995. 'Student attitudes to student debt', Journal of Economic Psychology, 16: 663-679.

Dixon, B.R. 1987. A handbook of social science research. New York, USA: Oxford University Press.

RSA. Dept of Trade and Industry. 2003. South African economic transformation strategy for broad based black empowerment. Pretoria, SA: DTI.

Duesenberry, J.S. 1949. Income, saving, and the theory of consumer behaviour. Cambridge, USA: Harvard University Press.

Eastman, J.K., Fredenberger, B., Campbell, B. \& Calvert, S. 1997. 'The relationship between status consumption and materialism: A cross-cultural comparison of Chinese, Mexican and American students', Journal of Marketing Theory and Practice, Winter: 52-66.

Fitzmaurice, J. \& Comegys, C. 2006. 'Materialism and social consumption', The Journal of Marketing Theory and Practice, 14(4): 287-299.
Futuse, M. 2006. 'Put brakes on your indebtedness'. City Press, 14 May: 5.

Ger, G. \& Belk R.W. 1990. 'Measuring and comparing materialism cross-culturally', Advances in Consumer Research, 17: 186-192.

Ger, G. \& Belk R.W. 1996. 'Cross-cultural differences in materialism', Journal of Economic Psychology, 17(1): 5577 .

Griffin, M., Babin, B.J. \& Christensen. 2004. 'A crosscultural investigation of the materialism construct: Assessing the Richins and Dawson's materialism scale in Denmark, France and Russia', Journal of Business Research, 57: 893-900.

Hair, J.F., Money, A.H., Samouel, P. \& Page, M. 2007. Research methods for business. England, UK: John Wiley and Sons Ltd.

Halasz, R. 2004. 'International directory of company histories, 75.' [online] URL :http://findarticles.com/. Accessed: 10 August 2009.

Heslin, R. \& Frey, K.P. 1996. Initial description of the consumer personality questionnaire. Working Paper, Purdue University.

Hofstee, E. 2006. Constructing a good dissertation: A practical guide to finishing a Master's, MBA or PhD on schedule. Johannesburg, South Africa: EPE.

Human Sciences Research Council. 2003. Household indebtedness in South Africa in 1995 and 2000. Pretoria, South Africa: Micro Finance Regulatory Council.

Hurwitz, I. \& Luiz, J. 2007. 'Urban working class credit usage and over-indebtedness in South Africa', Journal of Southern African Studies, 33(1):107-131.

Inglehart, R. 1981. 'Post- materialism in and environment of insecurity', The American Political Science Review, 75(4): 880-900.

International Finance Corporation (IFC). 2007. The next 4 billion: Market size and business strategy at the base of the pyramid. Washington, USA: World Resources Institute.

Kasser, T. \& Sheldon, K.M. 2000. 'Of wealth and death: Materialism, mortality salience and consumption behaviour', Psychological Science, 11(4):348-351.

Keller, G. 2005. Statistics for management and economics. 7th Edition. Mason, USA: Thomson South-Western.

Kingdon, G.G. \& Knight, J. 2007. 'Community, comparisons and subjective well-being in a divided society', Journal of Economic Behaviour and Organisation, 64(1): 69-90. 
Lerman, D. \& Maxwell, S. 2006. 'Joining a consumer society: Russian immigrant versus American materialism', Journal of Consumer Behaviour, 5(6): 479-490.

Mafu, T. 2007. 'Household data may mask indebtedness'. The Star, 13 April: 4.

Maslow, A. 1970. Motivation and personality. New York: Harper and Row.

Micken, K.S. 1995. 'A new appraisal of the Belk materialism scale', Advances in Consumer Research, 22: 398-405.

Mouton, J. 2001. How to succeed in your Master's and Doctoral studies: A South African guide and resource book. Pretoria, SA: Van Schaik Publishers.

Nunnally, J.C. 1978. Psychometric theory. New York, USA: McGraw-Hill.

Ponchio, M.C. \& Aranha F. 2008. 'Materialism as a predictor variable of low income consumer behavior when entering into installment plan agreements', Journal of Consumer Behaviour, 7: 21-34.

Prahalad, C.K. 2006. The fortune at the bottom of the pyramid. New Jersey, US: Wharthon School Publishing.

Prinsloo, J.W. 2002. Household debt, wealth and saving. Quarterly Bulletin, December 2002. Pretoria: South African Reserve Bank.

Prinsloo, J.W. 2000. The saving behaviour of the South African economy. Occasional Paper No 14, November 2000. Pretoria: South African Reserve Bank.

Richins, M.L. 2004. 'The material values scale: Measurement properties and development of a short form', Journal of Consumer Research, 31: 209-219.

Richins, M.L. 1987. 'Media, materialism, and human happiness', Advanced in Consumer Research, 14: 111-135.

Richins, M.L. Dawson, S. 1992. 'A consumer values orientation for materialism and its measurement: Scale development and validation', Journal of Consumer Research, 19: 303-316.

Richins, M.L. \& Dawson, S. 1990. 'Measuring material values: A preliminary report of scale development', Advances in Consumer Research, 17: 169-175.

Richins, M. \& Rudmin, F.W. 1994. 'Materialism and economic psychology', Journal of Economic Psychology, 15: $217-232$.

Rudmin, F.W. 1988. 'Ownership as interpersonal dominance: A history and three studies of the social psychology of property'. Doctoral Thesis, Queen's University, Kingston, Ontario, Canada.
Rutherford, S. 1999. The poor and their money. New Dehli, India: Oxford University Press.

Sangkhawasi, T. \& Johri, L.M. 2007. 'Impact of status brand strategy on materialism in Thailand', Journal of Consumer Marketing, 24(5): 275-282.

Sawady, E.R. \& Teschner, J. 2008. 'Financial decisionmaking processes of low-income individuals'. In Retsinas, N.P. \& Belsky, E.S. (Eds.). Borrowing to live: Consumer and mortgage credit revisited. Washington, USA: The Brookings Institution, p.p.92-109.

Schussler, M. 2003. 'South Africa's silent crisis', Mail \& Guardian, 1 April.

Seneca, P.J. 2002. 'A validation study of the Ger and Belk (1996) materialism scale and the Richins (2004) shortened material values scale'. Master's thesis, Graduate School Southern Illinois University, Carbondale, USA.

South African Reserve Bank (SARB). 2009. Quarterly Bulletin. Online Statistical Queries, South African Reserve Bank. [online] URL: http://www.reservebank.co.za/. Accessed 29 December 2009.

Sudbury, L. \& Simcock, P. 2009. 'A multivariate segmentation model of senior consumers', Journal of Consumer Marketing, 26(4): 251-262.

Tambyah, S.K., Mai, N.T.T. \& Jung, K. 2009. 'Measuring status orientations: Scale development and validation in the context of an Asian transitional economy',The Journal of Marketing Practice and Theory, 17(2):175-187.

Tatzel, M. 2003. 'The art of buying: Coming to terms with money and materialism', Journal of Happines Studies, 4(4): 405-435.

Vleggaar, F. 1978. 'The causes and effects of the relatively high risk of non-white credit in the retail fashion industry'. Master's Thesis. University of Stellenbosch.

Von Boven, L. 2005. 'Experientialism, materialism and the pursuit of happiness', Review of General Psychology, 9(2):132-142.

Walker, C.M. 1996. 'Financial management, coping and debt in households under financial strain', Journal of Economic Psychology, 17(6):789-807.

Wallendorf, M. 1988. 'My favourite things: a cross-cultural enquiry into object attachment, possessiveness and social linkage', Journal of Consumer Research, 14(4): 531-547.

Walliman, N. 2005. Your research project. $2^{\text {nd }}$ Edition. London, UK: SAGE.

Ward, S. \& Wackman, D.1971. 'Family and media influences on adolescent learning', American Behavioral Scientist, 14: 415-427. 
Watson, J.J. 1998. 'Materialism and debt: A study of current attitudes and behaviours', Advances in Consumer Research, 25: 203-207.

Watson, J.J. 2003. 'The relationship of materialism to spending tendencies, saving, and debt', Journal of Economic Psychology, 24: 723-739.

Webster, C. \& Beatty, R.C. 1997. 'Nationality, materialism, and possession importance', Advances in Consumer Research, 24: 204-210.

World Bank. 2007. 2007 World Development Indicators. Washington: The World Bank. 